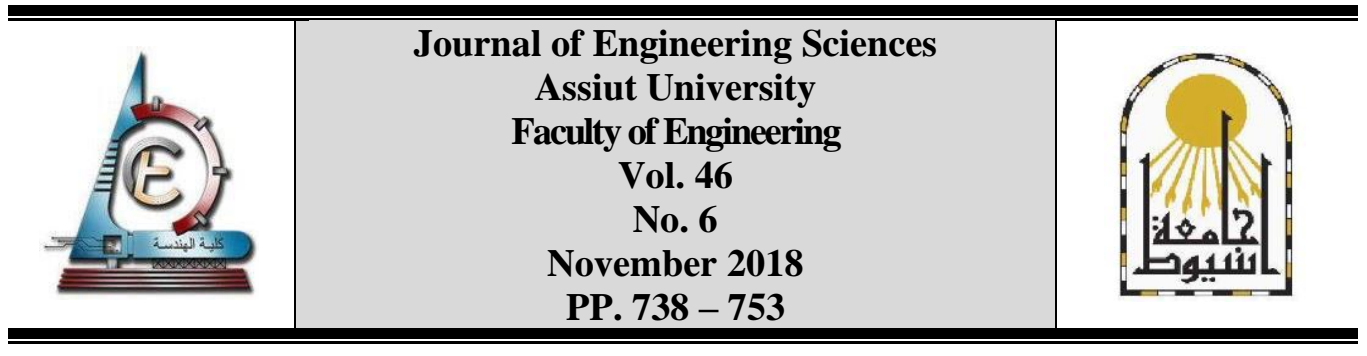

\title{
EFFECT OF GREEN ROOF DESIGN ON ENERGY SAVING IN EXISTING RESIDENTIAL BUILDINGS UNDER SEMI-ARID MEDITERRANEAN CLIMATE (AMMAN AS A CASE STUDY)
} AHMED ABDIN ${ }^{1}$, KHALID EL DEEB ${ }^{2}$, SHAHAD A.M. AL-ABBASI ${ }^{*}, 3$

\author{
${ }^{1,3}$ Department of Architecture, Cairo University. \\ ${ }^{2}$ Architecture Department, Alexandria University.
}

Received 9 August 2018; Accepted 13 August 2018

\begin{abstract}
In Jordan, residential buildings consume up to $48 \%$ of electrical energy, a significant amount of almost the half of energy goes for heating. Green roof is one of the passive techniques that improves energy performance. This paper examines the energy performance and Carbon Dioxide $\left(\mathrm{CO}_{2}\right)$ reduction of the green roof technology in the semi-arid Mediterranean climate of Amman by considering a typical apartment in Jordanian residential building as a case study. The effect of soil thickness, air gab and irrigation were determined for the performance of extensive green roof regarding to their plant. Malva Parviflora has been chosen for study. The base case model annual energy consumption has been determined by DesignBuilder software without a green roof installed. The result shows that installing extensive green roof saves annual energy consumption up to $14.25 \%$.
\end{abstract}

Keywords: Extensive Green Roof, Residential Building, $\mathrm{CO}_{2}$, Reduction, Energy Efficiency, Amman, Semi-Arid Mediterranean Climate.

\section{Introduction}

Choosing Amman for the case study is due to the high rate of investments in building industry over the last decades and the raise of electric energy consumption at residential sector. Amman represents $40 \%$ of the total housing stock in Jordan [1]. With total population of 9.5 million and more than 4 million of them live in the capital Amman [2]. Considering the trends of land use/cover change and population growth, its likely to increase the land use/cover $1.7 \%$ of the total area in year 2010 to 2030, which is the double of land use [3].

During the past three years, power generation level in Jordan was critical, and sometimes fell short behind the demand. In the near future, Jordan will remain a net importer of oil and natural gas from the Arab neighboring countries, especially Iraq, Saudi Arabia and Kuwait as well as electricity from Egypt [4]. These energy imports account for

* Corresponding author.

Email address: shahad_alabbasi@yahoo.com 
more than $40 \%$ of the country's budget [5]. The annual increase in the demand for electricity in the Jordan is around 5.5\% [6].

Residential buildings in Jordan consume a significant amount of electricity up to $45 \%$ of total electrical in 2016 according to Ministry of Energy and Mineral Resources [7]. The demand on the primary energy sources in Jordan has been growing at an average annual rate of $4 \%$ over the past ten years. It is expected to continue in growing at an average annual rate of $3 \%$ during the next decade. However, the demand on electrical energy is growing much faster [8]. In contrast, the Ministry of Energy \& Mineral Resources estimates that demand for energy will grow annually at an average of $5.1 \%$ with the demand for electricity in particular rising by an average of $6.4 \%$ annually [9].

As this sense started to rise within the concerned bodies in the developing region. In addition to energy use, the associated Green House Gas (GHG) emissions and their potential effects on the global climate change are nowadays a worldwide concern. According to the World Bank, $\mathrm{CO}_{2}$ emission in Jordan has been increased from $744(\mathrm{kt})$ in 1960 to $26,450(\mathrm{kt})$ in 2014 [10].

\section{Objectives}

Since residential buildings in Amman are responsible for almost the half of electricity, the intent of this paper is to provide an experimental base that describe the potential of green roof impact on energy saving. Also, the effect of soil thickness, air gab and irrigation when vegetated roof, is installed on energy saving and $\mathrm{CO}_{2}$ reduction.

\section{Literature review}

Green roof is a specialized roofing system that supports vegetation growth on rooftops and can be retrofitted on existing buildings without requiring structural changes. There are many reported benefits that the installing of a green roof to a building can offer. One of these benefits is the potential for building energy savings where a green roof system can reduce annual cooling and heating demands and $\mathrm{CO}_{2}$ production. From the large body of literature published over the past 20 years, we deduce that green roof adoption is driven by various motivations, included energy saving and $\mathrm{CO}_{2}$ reduction which are two main problems of this study. This technology is rapidly gaining popularity in Germany and North America as a sustainable design option. Green roof contain many layers such as soil layer, container layer, air gap and top of all the plants. Some of green roofs have also a drainage layer.

A previous experiment in Lisbon, Portugal to quantifies green roof energy saving in Mediterranean climate. The result of extensive field experiments in Mediterranean climate of green roof and different insulation properties was compared to traditional roof solutions, led to conclusion that with no thermal insulation, extensive green roof requires $20 \%$ less energy than plain roof [11]. Another study was another step of a long-term work to study the thermal behavior of extensive green roofs in dry Mediterranean Continental climate took place in Puigverd de Lleida, Spain. The energy consumption of cubicle green roof reduces from $3.5 \%$ to $15 \%$ comparing to the reference cubicle [12].

Further analyses on the impact of green roof on the energy consumption in Jordan were performed by measuring the annual energy consumption in HVAC system by comparing the green roofs with the conventional roofs. Energy consumption analyses indicate that 
green roofs have better performance than regular roofs. Total annual energy consumption was dropped by approximately $11 \%$ when using green roof instead of the regular one [13].

An experimental study carried out on an extensive green roof under similar climate conditions, the aim of it was to analyses the thermal performance of a green roof during the summer. It was found that the green roof reduced cooling consumption of $60 \%$ in comparison to a conventional roof [14]. One of the most important parameters that affect green roof performance is soil thickness. A lightweight of less than $200 \mathrm{~mm}$ deep that do not represent an excessive overweight for conventional roof structures $(70-170 \mathrm{~kg} / \mathrm{m} 2)$ with shallow layer of growing substrate [15].

Another model with two stories residential building in Cairo, Egypt with a base case control which uses a traditional roof that meets standard model energy code was simulated while changing the conductivity and the thickness of the green-roof soil. The results showed that savings varied from 15-32\% compared to traditional and un-isolated roofs [16]. Other study by Issa Jaffal, Salah-Eddine Ouldboukhitine and Rafik Belarbi, aims to provide a comprehensive study of the influence of a green roof on building energy performance. Results showed that the annual energy load was reduced by 6\% [17]. On the other hand, it is known that green roof is one of the green strategies which is adopting in building sectors for rapid urbanization influence reduction [18]. Plants on the roofs absorb suspended particles and heavy metal compounds in air and disintegrate them [19]. By absorbing gas pollutants through their holes and separating pollutants in their leaves, also disintegrating special organic compounds such as poly-aromatic hydrocarbon in the plant tissues or soil, green roof plays a positive role in improving air quality because they resist air pollution [20]. According to the researcher knowledge, the 'air gap' parameter was studied only as an input data, the present study will investigate the impact of deferent thickness of air gap.

\section{Materials and methods}

This section describes the methodology of evaluating the amount of energy saving influenced by the main variables that effect extensive green roof for existing residential buildings south orientation of an apartment that was designed to meet the real typical high standards apartments in Amman, the roof is a conventional flat roof. The tested simulation model was set up using AutoCad, then annually energy simulation is carried out for the baseline and installing of extensive green roof under semi-arid Mediterranean climatic which results in certain energy consumption and $\mathrm{CO}_{2}$ production. Energy simulation, in the present study, uses the data driven modeling to identify and complete the simulation input setting by DesignBuilder simulation software as it is an advanced building energy simulation program to analyses.

Extensive green roofs are used for this study and are only a few centimeters thick with vegetation. Four thicknesses of green roofs were applied as it does not require an additional construction for existing buildings. The experiment was conducted in two phases. The first phase determine the energy consumption of typical common traditional materials residential apartment for south orientation, to compare it's energy performance with the green roof as well as $\mathrm{CO}_{2}$ reduction. Phase two determine the effect of soil and air gab layer thickness on energy consumption. Moreover, the impact of changing irrigation schedule was determined.

\subsection{Base-case building}

The model was selected as an existing typical newly constructed First-Class apartment with apartment areas ranges between $140-150 \mathrm{~m}^{2}$ as shown in Figure 1 that is commonly 
spread of Jordanian residential buildings type located in the city of Amman [13]. Residential buildings in Jordan consist of four-story, proposed to be rectangular as a widely used building from. Hence, its dimensions worked out as $(8 \mathrm{~m}(\mathrm{~W})$ x $18 \mathrm{~m}$ (L) x 2.7 $\mathrm{m}(\mathrm{h})$ ) contains 8 residential units ( 2 units per floor); the area of each unit is $141 \mathrm{~m}^{2}$.

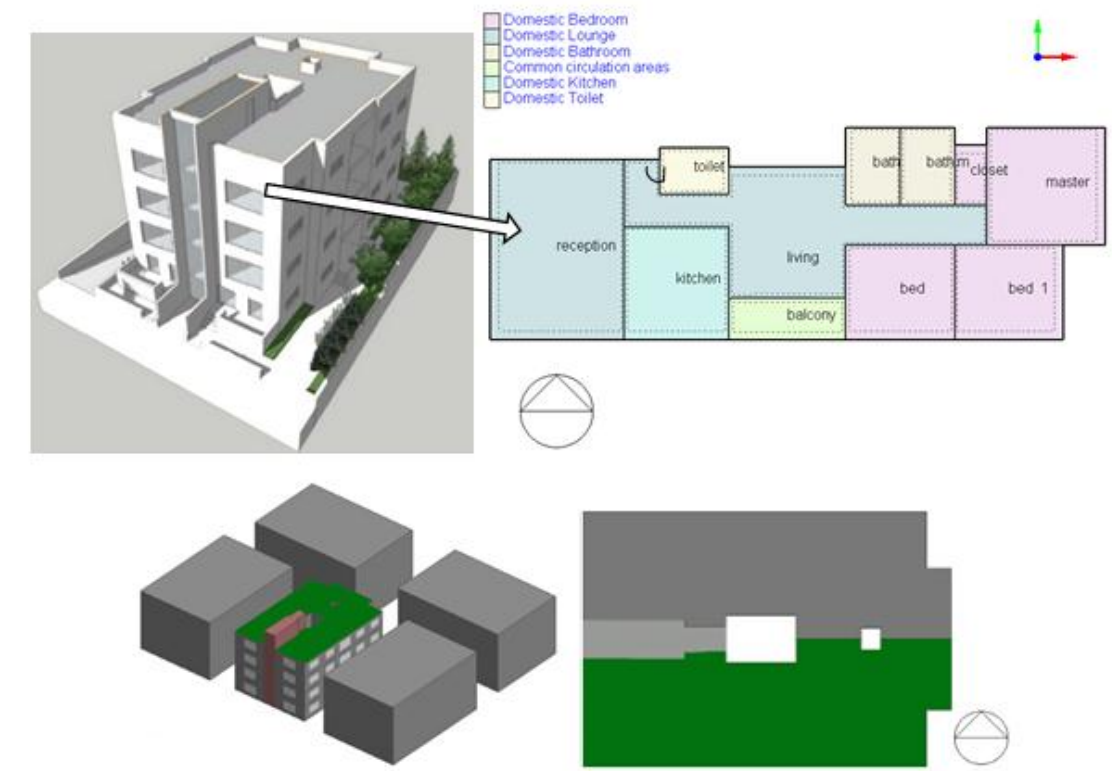

Fig. 1. A View for a Residential Building in Jordan Before \& After Installing of Green Roof

Each apartment that includes a living room, guest room, kitchen, 3 bedrooms, 2 bathrooms, toilet, balcony and 2 corridors. Each apartment has a complementary water tank on the building top roof. The building construction is of concrete post and column structure with hollow block envelope and stone veneer as an external finish. The roof is flat and the average floor height is $2.7 \mathrm{~m}$. The apartment occupants represent uppermiddle-class families of an average Jordanian family (5 person/apartment) [21].

User pattern follows the typical cultural model in Jordan, such as family size, user behavior (opening and closing windows for ventilation) and domestic energy use. The empirical simulation will apply to an initial model, whose specifications are identified hereunder, where the used software is already equipped as summarize in Table 1. To select base case energy use characteristics, a compliant single-family semi-detached apartment was modeled in AutoCad software and simulation was run in Amman climate zone by DesignBuilder. The construction type, HVAC (Heating, Ventilation, and Air Conditioning) and DHW (Domestic Hot Water) system types were determined from the housing survey data by the Public Action Project and Jordan Green Building Council. The climate zone of Amman in the DesignBuilder software is $(3 \mathrm{C}$ ) according to ASHRAE (American Society of Heating, Refrigerating, and Air-Conditioning Engineers). Annual energy consumption will be determined when the longest façade is facing south as it's the best orientation for the climate of Amman according to the JNBC (National Jordanian Building Council) [22]. 
JES, Assiut University, Faculty of Engineering, Vol. 46, No. 6, November 2018, pp.738-753

Table 1.

Base-case Building Characteristics

\begin{tabular}{|l|l|}
\hline \multicolumn{2}{|c|}{ Specific Climate Characteristics } \\
\hline Climate & Semi-arid Mediterranean \\
\hline City & Amman \\
\hline Latitude and Longitude & $31.9-35.9$ \\
\hline Altitude & 784 \\
\hline ASHRAE Zone & 3 C \\
\hline \multicolumn{2}{|c|}{ Apartment Characteristics } \\
\hline Building Configuration & 144 m$^{2}$, rectangle-shape, three elevations \\
\hline Plan Shape & $1: 3$ \\
\hline Construction Type & $\begin{array}{l}\text { Reinforced-concrete post and beam structure with brick infill } \\
\text { walls }\end{array}$ \\
\hline Ceiling High & 2.7 m \\
\hline Materials & Common, Traditional \\
\hline Color & Wall: white - Roof: grey \\
\hline WWR\% & $15 \%$ \\
\hline Glass Type & Single Clear 6 (mm) \\
\hline Occupancy & 5 persons, Density 0.0395 (people/ m2) \\
\hline DHW & $24 / 7$ at winter, 1 h/d at summer \\
\hline Lighting & Led \\
\hline \multicolumn{2}{|c|}{ General Characteristics } \\
\hline HVAC System & Split unit \\
\hline DHW & 80 -litre electric water heater, 0.86 energy factor \\
\hline Thermal set point & $18 C^{\circ}$ for Winter and 28C ${ }^{\circ}$ for Summer \\
\hline Ventilation & $\begin{array}{l}\text { In summertime, natural ventilation is used in night cooling of the } \\
\text { building. All openings can be operated manually by the users. }\end{array}$ \\
\hline \multicolumn{2}{|l|}{ Orientation } \\
\hline $\begin{array}{l}\text { Orientation of the longest } \\
\text { facade }\end{array}$ & \begin{tabular}{l} 
South \\
\hline Other Exposed Walls
\end{tabular} \\
\hline Wall Party & \multicolumn{2}{|c|}{ West, East } \\
\hline
\end{tabular}

\subsubsection{Envelope layers}

Table 2 provide the envelope of building details that were considered for the traditional model of this study. Each apartment has three types of walls, external, internal and wall party. Little/no heat exchange is expected to occur with the neighboring apartment, UValue $=2$ according to the Jordanian Code Complains [23] 
Shahad a.m. al-Abbasi et al., Effect of green roof design on energy saving in existing

Table 2.

Traditional Residential Buildings Layers Materials and Thermal Properties Modeled on the Software

\begin{tabular}{|c|c|c|c|}
\hline & Elements (from out to in) & Thickness (mm) & Performance \\
\hline \multirow{8}{*}{$\begin{array}{l}\stackrel{4}{\circ} \\
\stackrel{2}{\alpha}\end{array}$} & Ceramic Tile & 25 & \multirow{8}{*}{$\begin{array}{c}\text { U-Value }\left(\mathrm{W} / \mathrm{m}^{2}\right) \\
=1.183\end{array}$} \\
\hline & Cement Mortar & 10 & \\
\hline & Sand & 70 & \\
\hline & Water Proofing Bitumen Roll (200gm.m²) & 4 & \\
\hline & Sloping Lightweight Concrete/450.m3 density & 150 & \\
\hline & RC. Concrete & 310 & \\
\hline & Plaster & 25 & \\
\hline & Emulsion Paint & 0.5 & \\
\hline \multicolumn{3}{|c|}{ Total $=60 \mathrm{~mm}$} & \\
\hline \multirow{5}{*}{ 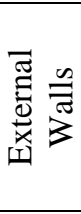 } & Stone Veneer & 50 & \multirow{5}{*}{$\begin{array}{c}\text { U-Value }\left(\mathrm{W} / \mathrm{m}^{2}\right) \\
=1.102\end{array}$} \\
\hline & Concrete & 150 & \\
\hline & Concrete Hollow Block & 100 & \\
\hline & Plaster & 25 & \\
\hline & Emulsion Paint & 0.5 & \\
\hline & \multicolumn{2}{|l|}{ Total $=33 \mathrm{~mm}$} & \\
\hline
\end{tabular}

\subsubsection{Window}

Windows are single glazed $(6 \mathrm{~mm})$ with U-Value of 5.778, transparent. The window to wall ratio (WWR) that is, the ratio between the window size and wall area expressed in $\%$ is $15 \%$ as it's the minimum allowed ratio for residential buildings [22]. In this study, the commercial type of aluminum frame is included.

Doors are $50 \mathrm{~mm}$ thick wood with storm protection capability for outdoors. In addition, external roller shutter on window, extruded aluminum, white or brown coat shading devices admit a low angle sun in the morning or winter when passive heating is needed, screen the sun in the middle of the day and in summer when overheating is a risk. The overhang will be cantilevered (balcony) for 1 meter, to protect the living room from the sun between May and September. Table 3 shows the glass type characteristics.

Table 3.

Window Characteristics

\begin{tabular}{|c|c|c|c|c|}
\hline \multirow[b]{2}{*}{$\begin{array}{l}\text { Elements } \\
\text { (from out to in) }\end{array}$} & \multicolumn{2}{|c|}{ Single Pane } & \multicolumn{2}{|c|}{ Double Pane } \\
\hline & $\begin{array}{l}\text { Thickness } \\
(\mathrm{mm})\end{array}$ & Performance & $\begin{array}{l}\text { Thickness } \\
(\mathrm{mm})\end{array}$ & Performance \\
\hline $\begin{array}{l}\text { Clear, White or Brown Coat, } \\
\text { Aluminum Sliding and Frame }\end{array}$ & 6 & $\mathrm{U}=5.778$ & 24 & $\begin{array}{c}\mathrm{U}=2.665 \\
\text { Required } \\
=2.8\end{array}$ \\
\hline $\begin{array}{l}\text { SHGC: Solar Heat Gain } \\
\text { Coefficient }\end{array}$ & & 0.84 & & 0.73 \\
\hline $\begin{array}{l}\text { VLT: Visible Light } \\
\text { Transmittance }\end{array}$ & & 0.89 & & 0.79 \\
\hline $\begin{array}{l}\text { External Roller Shutter on } \\
\text { Window, Extruded Aluminum, } \\
\text { White or Brown Coat }\end{array}$ & & $\sqrt{ }$ & & $\sqrt{ }$ \\
\hline
\end{tabular}




\subsection{Green roof designs}

This study conducted simulations of twenty eight different scenarios considering different soil thickness, air gab and irrigation. From this point forward (ST) refers to soil thickness. Selected plants will be among the available choices in Amman. As the planted roof is for residential buildings, selected plants should require minimum or no maintenance, constitute the vegetation layer.

\subsubsection{Soil thickness (ST)}

Soil thickness should be between $10-25 \mathrm{~cm}$ as the system is extensive green roof because their smaller load does not require additional strengthening, the plants which suite this soil thickness is low growing succulents and annual to biennial plants, herbaceous perennials [24]. Four thicknesses of a typical extensive green roof have been designed in order to assess their energy performances in comparison to plain roof.

\subsubsection{Leaf area index (LAI)}

LAI define equally the one sided green area of leaf per unit ground surface area, it defers from plant to other. In Amman, plantation stores are very common, plants divers from low growing succulents, shrubs and turf to small trees, prices depend on plant type and its volume. Generally, a pot of flowers starts from 0.5 Jordanian Dinar (JOD) which equal to 0.7 U.S. dollars (USD), fig 2 shows some of plantation stores an Amman. Table 4 includes some of usable plants in Amman.
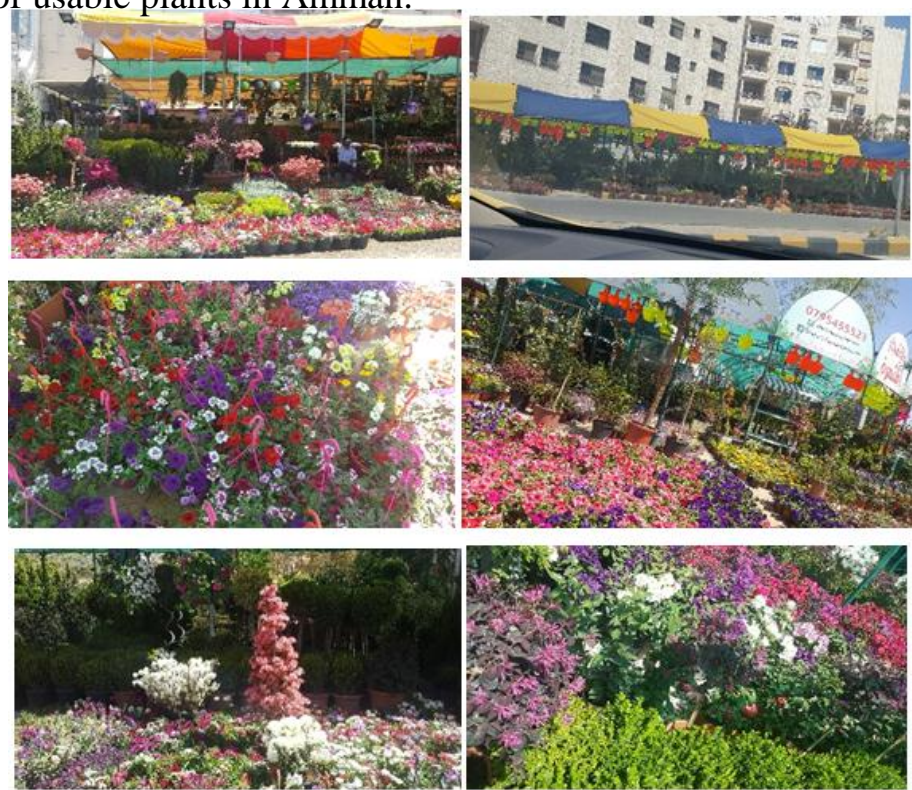

Fig. 2. Plantation Stores \& Plants Variety in Amman (Researcher 2018)

The researcher asked several plantation stores about the kinds of vegetation that people use in their apartment weather for garden or balcony. Successful candidates for extensive green roofs must exhibit characteristics such as easy propagation, rapid establishment, and high ground cover density [25]. The researcher recommended Malva Parviflora as has all mentioned characteristics. In addition, it is suitable for little soil thickness, doesn't need heavy irrigation; also it's the cheapest among the plants in Amman. Moreover, it has a medical benefit. Leaf area index for it is 5 . 
Shahad a.m. al-Abbasi et al., Effect of green roof design on energy saving in existing

Table 4.

Some of Current Usable Plants Factors in Amman

\begin{tabular}{|c|c|c|c|c|c|c|c|}
\hline & $\begin{array}{l}\text { Botanical } \\
\text { Name }\end{array}$ & Type & $\begin{array}{c}\text { Soil } \\
\text { Thickness } \\
(\mathrm{cm}) \\
\end{array}$ & LAI & Season & $\begin{array}{c}\text { Sun } \\
\text { Exposure }\end{array}$ & $\begin{array}{c}\text { Water } \\
\text { Requirements }\end{array}$ \\
\hline 1 & Petunia & $\begin{array}{l}\text { herbaceous per } \\
\text { ennial }\end{array}$ & $10-15$ & $4-5$ & Evergreen & Full sun & Little \\
\hline 2 & $\begin{array}{l}\text { Fragaria } \\
\text { Virginiana }\end{array}$ & $\begin{array}{l}\text { herbaceous per } \\
\text { ennial }\end{array}$ & $10-15$ & $4-5$ & Seasonal & $\begin{array}{l}\text { Full sun to } \\
\text { partial shade }\end{array}$ & Medium \\
\hline 3 & $\begin{array}{l}\text { Cichorium } \\
\text { Intybus }\end{array}$ & $\begin{array}{l}\text { herbaceous per } \\
\text { ennial }\end{array}$ & $10-15$ & NA & Seasonal & Full sun & Medium \\
\hline 4 & African daisy & Small Shrub & 25 & $4-5$ & $\begin{array}{l}\text { Evergreen, } \\
\text { seasonal }\end{array}$ & $\begin{array}{l}\text { Full sun to } \\
\text { partial shade }\end{array}$ & Medium \\
\hline 5 & $\begin{array}{l}\text { Malva } \\
\text { Parviflora } \\
\end{array}$ & $\begin{array}{l}\text { Herbaceous } \\
\text { perennial }\end{array}$ & $10-15$ & $4-5$ & Evergreen & Full sun & Little \\
\hline 6 & Mint & Herbaceous & $10-15$ & $4-5$ & Seasonal & Partial shade & Heavy \\
\hline 7 & Crassulaceae & $\begin{array}{l}\text { low growing } \\
\text { succulents }\end{array}$ & $10-15$ & $4-5$ & $\begin{array}{l}\text { Evergreen, } \\
\text { seasonal }\end{array}$ & Full sun & Little \\
\hline
\end{tabular}

\subsubsection{Coverage and growth}

In most situations planting is best completed between autumn and early spring. This will assist plant establishment and growth, well before the warmer and drier conditions of summer, so can maximize its performance due to shading. Plants will often establish best on-site. Ecology, LEED (Leadership in Energy and Environmental Design) has proposed that green roof coverage to be $100 \%$.

Considering that green roof plants takes several months to become fully established, the plant coverage of $100 \%$ (fully covered with plants) was considered in this study.

In addition, Table 5 shows Malva Parviflora characteristics.

Table 5.

Malva Parviflora Characteristics

\begin{tabular}{|c|c|c|}
\hline \multicolumn{2}{|c|}{$\begin{array}{c}\text { Criteria \& } \\
\text { Botanical Name }\end{array}$} & \\
\hline \multicolumn{2}{|l|}{ Type } & herbaceous \\
\hline \multicolumn{2}{|l|}{ Substrate Option } & $10-15 \mathrm{~cm}$ \\
\hline \multicolumn{2}{|l|}{ LAI } & $4-5$ \\
\hline \multicolumn{2}{|l|}{ Irrigation } & Two times weekly in summer - Once weekly in winter \\
\hline \multirow[t]{2}{*}{ Benefits } & Production & has several uses in traditional medicinal practice \\
\hline & Atheistic & Flowers: white pink red purple \\
\hline \multirow[t]{2}{*}{ Weather Tolerance } & Exposure & Full sun to part shade \\
\hline & Cold & $\sqrt{ }$ \\
\hline \multirow[t]{2}{*}{ Maintenance } & Low & $\sqrt{ }$ \\
\hline & Expensive & - \\
\hline \multicolumn{2}{|l|}{ Growing attributes } & evergreen \\
\hline \multicolumn{2}{|l|}{ High } & Up to $12 \mathrm{~cm}$ \\
\hline \multicolumn{2}{|l|}{ Cost } & Cheap \\
\hline
\end{tabular}




\subsubsection{Irrigation}

Selected plants must need small amount of water due to water poverty in Jordan. At the same time, a simple irrigation system should be installed to ensure the survival of plants in the summer months under Continental Mediterranean climate conditions. Moreover, grey water can be used if system is available in residential buildings. Selected plant needs average 2 times weekly, off at winter [26]. However, simulations were carried out for two times schedule and seven days weekly to determine the impact of irrigation.

'Drip' is the most efficient because the sun and wind can prevent sprayed water from reaching the plants [27]. On the other hand, buildings in Amman are designed to protect roofs from rain and snow in winter. With annual rainfalls in Amman in the mountains ranges between $300 \mathrm{~mm}$ and $600 \mathrm{~mm}$ [28], there is no worries from bad irrigation manners.

\section{Results}

The results demonstrate energy saving and environmental benefits of using green roofs under different soil thicknesses, air gab and irrigation schedule for typical apartment in Amman.

\subsection{Phase one: energy performance and $\mathrm{CO}_{2}$ production of plain roof}

When ratio of apartment plan shape is $1: 3$, ceiling high is $2.7 \mathrm{~m}$, WWR is $15 \%$, glass type is single clear $6 \mathrm{~mm}$ and construction is due to common traditional materials and plain, simulation results showed that when apartment is facing South, it consumes $77.95\left(\mathrm{kWhr} / \mathrm{m}^{2}\right)$, annual heating load is $33.07(\mathrm{kWh})$, annual cooling load is $12.37(\mathrm{kWh})$ with annual $\mathrm{CO}_{2}$ production of $6802.30(\mathrm{~kg})$. Energy consumption per capita in this results was $2340(\mathrm{kWhr})$ comparing to $2483(\mathrm{kWhr})$ according to the report of Ministry of Energy and Mineral Resources [7]. Energy consumption per capita in this results $2340(\mathrm{kWhr})$ comparing to $2483(\mathrm{kWhr})$ according to the report of Ministry of Energy and Mineral Resources [7].

\subsection{Phase two: green roof performance}

Comparing between soil thicknesses of extensive green roof with deferent air gap that can be added to existing residential buildings. Increasing ST in this case study, it shows that it has a little impact on overall U-Value of the roof layers as shown in table 6 . The results of annual energy consumption of residential buildings for deferent green roof designs in shown in table 7 .

Table 6.

Comparing U-value of Deferent Roof Design

\begin{tabular}{|c|c|c|c|c|c|c|}
\hline \multirow[t]{2}{*}{ Roof Type } & \multicolumn{2}{|c|}{ Green Roof Design } & \multirow{2}{*}{$\begin{array}{c}\text { U-Value } \\
\text { ST }\end{array}$} & \multicolumn{2}{|c|}{ Green Roof Design } & \multirow{2}{*}{$\begin{array}{c}\text { U-Value } \\
\text { ST }\end{array}$} \\
\hline & ST & Air Gab $(\mathrm{cm})$ & & ST & Air Gab $(\mathrm{cm})$ & \\
\hline Plain & \multicolumn{2}{|r|}{---} & 0.542 & \multicolumn{3}{|c|}{---} \\
\hline \multirow{10}{*}{ Green } & \multirow{5}{*}{10} & --- & 0.450 & \multirow[t]{5}{*}{20} & --- & 0.391 \\
\hline & & 2 & 0.409 & & 2 & 0.360 \\
\hline & & 5 & 0.409 & & 5 & 0.360 \\
\hline & & 10 & 0.409 & & 10 & 0.360 \\
\hline & & 50 & 0.409 & & 50 & 0.360 \\
\hline & \multirow{5}{*}{15} & --- & 0.418 & \multirow[t]{5}{*}{25} & 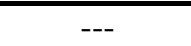 & 0.367 \\
\hline & & 2 & 0.383 & & 2 & 0.340 \\
\hline & & 5 & 0.383 & & 5 & 0.340 \\
\hline & & 10 & 0.383 & & 10 & 0.340 \\
\hline & & 50 & 0.383 & & 50 & 0.340 \\
\hline
\end{tabular}


Shahad a.m. al-Abbasi et al., Effect of green roof design on energy saving in existing

Table 7.

Comparing Energy Performance of Deferent Green Roof Designs, Irrigation: (two times weekly at summer, off at winter)

\begin{tabular}{|c|c|c|c|c|c|c|c|}
\hline 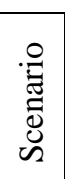 & $\underset{⿶}{\longleftarrow}$ & $\begin{array}{c}\mathrm{ST} \\
(\mathrm{cm})\end{array}$ & $\begin{array}{l}\text { Air } \\
\text { Gap } \\
(\mathrm{cm})\end{array}$ & $\begin{array}{c}\text { Annual energy } \\
\text { Consumption } \\
(\mathrm{kWh})\end{array}$ & $\begin{array}{c}\text { Annual } \\
\text { Heating Load } \\
(\mathrm{kWh})\end{array}$ & $\begin{array}{c}\text { Annual } \\
\text { Cooling Load } \\
(\mathrm{kWh})\end{array}$ & $\begin{array}{c}\text { Annual } \mathrm{CO}_{2} \\
\text { Production } \\
(\mathrm{kg})\end{array}$ \\
\hline 1 & \multirow{20}{*}{5} & \multirow[t]{5}{*}{10} & --- & 69.39 & 29.33 & 7.56 & 6055.69 \\
\hline 2 & & & 2 & 68.69 & 28.31 & 7.88 & 5994.31 \\
\hline 3 & & & 5 & 68.69 & 28.31 & 7.88 & 5994.31 \\
\hline 4 & & & 10 & 68.69 & 28.31 & 7.88 & 5994.31 \\
\hline 5 & & & 50 & 68.69 & 28.31 & 7.88 & 5994.31 \\
\hline 6 & & \multirow[t]{5}{*}{15} & --- & 68.36 & 28.06 & 7.80 & 5966.22 \\
\hline 7 & & & 2 & 67.77 & 27.33 & 7.94 & 5914.62 \\
\hline 8 & & & 5 & 67.77 & 27.33 & 7.94 & 5914.62 \\
\hline 9 & & & 10 & 67.77 & 27.33 & 7.94 & 5914.62 \\
\hline 10 & & & 50 & 67.77 & 27.33 & 7.94 & 5914.62 \\
\hline 11 & & \multirow[t]{5}{*}{20} & --- & 67.88 & 27.45 & 7.93 & 5923.56 \\
\hline 12 & & & 2 & 67.40 & 26.63 & 8.27 & 5882.27 \\
\hline 13 & & & 5 & 67.40 & 26.63 & 8.27 & 5882.27 \\
\hline 14 & & & 10 & 67.40 & 26.63 & 8.27 & 5882.27 \\
\hline 15 & & & 50 & 67.40 & 26.63 & 8.27 & 5882.27 \\
\hline 16 & & \multirow[t]{5}{*}{25} & $\overline{---}$ & 67.35 & 26.81 & 8.04 & 5877.79 \\
\hline 17 & & & 2 & 66.84 & 26.05 & 8.29 & 5832.76 \\
\hline 18 & & & 5 & 66.84 & 26.05 & 8.29 & 5832.76 \\
\hline 19 & & & 10 & 66.84 & 26.05 & 8.29 & 5832.76 \\
\hline 20 & & & 50 & 66.84 & 26.05 & 8.29 & 5832.76 \\
\hline
\end{tabular}

Table 8.

Comparing Energy Performance of Deferent Green Roof Design When Irrigation is (ON)

\begin{tabular}{|c|c|c|c|c|c|c|c|}
\hline 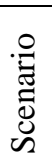 & 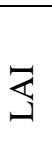 & $\begin{array}{c}\text { ST } \\
(\mathrm{cm})\end{array}$ & $\begin{array}{l}\text { Air } \\
\text { Gap } \\
\text { (cm) }\end{array}$ & $\begin{array}{c}\text { Annual energy } \\
\text { Consumption } \\
(\mathrm{kWh})\end{array}$ & $\begin{array}{c}\text { Annual } \\
\text { Heating Load } \\
(\mathrm{kWh})\end{array}$ & $\begin{array}{c}\text { Annual } \\
\text { Cooling Load } \\
(\mathrm{kWh})\end{array}$ & $\begin{array}{c}\text { Annual } \mathrm{CO}_{2} \\
\text { Production } \\
(\mathrm{kg})\end{array}$ \\
\hline 21 & \multirow{8}{*}{5} & \multirow[t]{2}{*}{10} & --- & 69.53 & 29.46 & 7.56 & 6067.54 \\
\hline 22 & & & 10 & 68.37 & 27.99 & 7.88 & 5966.86 \\
\hline 23 & & \multirow[t]{2}{*}{15} & --- & 68.53 & 28.22 & 7.80 & 5980.40 \\
\hline 24 & & & 10 & 67.60 & 27.16 & 7.94 & 5899.27 \\
\hline 25 & & \multirow[t]{2}{*}{20} & --- & 67.92 & 27.49 & 7.93 & 5927.49 \\
\hline 26 & & & 10 & 67.34 & 26.57 & 8.27 & 5877.10 \\
\hline 27 & & \multirow[t]{2}{*}{25} & --- & 67.36 & 26.82 & 8.04 & 5878.74 \\
\hline 28 & & & 10 & 67.04 & 26.25 & 8.29 & 5850.67 \\
\hline
\end{tabular}

\section{Discussion}

\subsection{Installing green roof}

Installing green roof has a positive impact on energy performance comparing with plain roof. When soil thickness is $25(\mathrm{~cm})$ and air gap is $2(\mathrm{~cm})$ or more, it decrease annual 
energy consumption up to $14.25 \%$, Fig 3. It also decrease annual heating and annual cooling load up to $21.24 \%$ and $32.98 \%$ respectively as shown in Fig. 4.

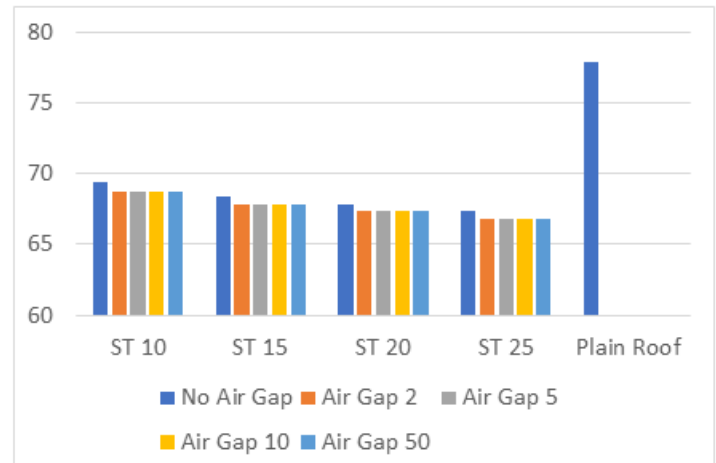

Fig. 3. Comparing EUI of Green Roof Performance for Deferent Soil Thickness (ST) and Air Gap With Plain Roof When Apartment is Facing South

\subsection{Effect of soil thickness}

Soil thickness has impact on u-value of green roof as shown previously in Table 6 . Increasing soil thickness layer from 10 to $25 \mathrm{~cm}$ and air gap is $2 \mathrm{~cm}$ (or more) has the following impact:

- Increase saving of annual energy by $2.69 \%$.

- Increase saving of annual heating by $7.99 \%$ because increase soil thickness act like an insulation, Fig 4 (left).

- Decrease saving of annual cooling by $5.2 \%$ because the thickness of soil will prevent the temperature inside the apartment from emitting through the roof by conduction, Fig 4 (right).

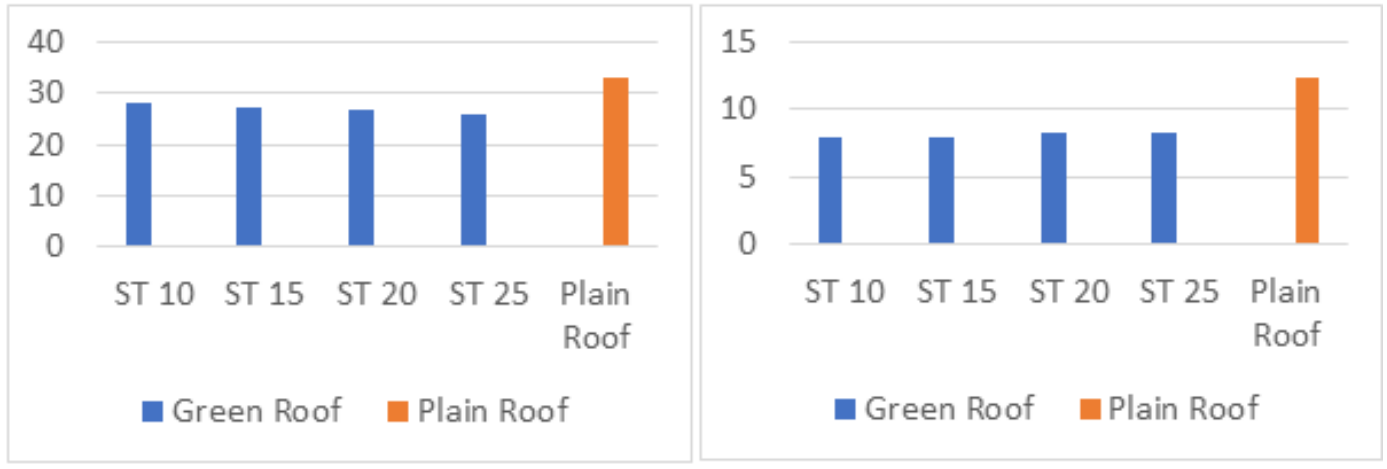

Fig. 4. Comparing Heating and Cooling Loads of Plain Roof and Green Roof With Deferent Soil Thickness (ST) (Left: Heating Load, Right: Cooling Load)

\subsection{Effect of air gap}

Air gap act like an insulation layer. Leaving $2 \mathrm{~cm}$ layer of air between soil and roof saves $0.76 \%$ of annual energy. Saves $2.85 \%$ and $3.1 \%$ of heating and cooling load respectively when soil thickness $25 \mathrm{~cm}$, Fig. 5. Moreover, increasing air gap layer more than $2(\mathrm{~cm})$ won't change the u-value or energy performance of green roof as shown previously in Fig. 3 . 


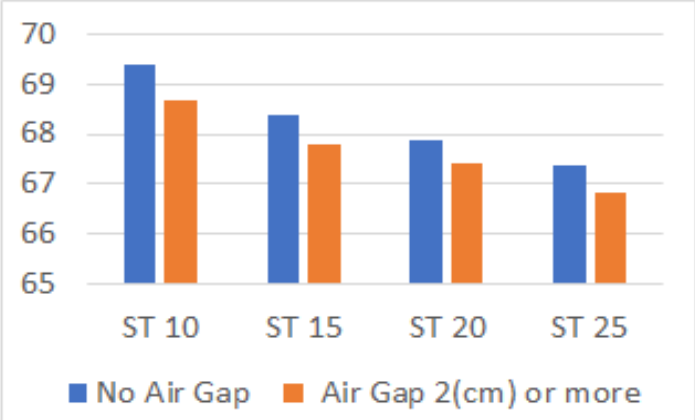

Fig. 5. Comparing Effect of Air Gap on Green Roof Performance for Deferent Soil Thickness (ST)

\subsection{Effect of irrigation}

Irrigation does not affect $\mathrm{u}$-value of green roof. Changing irrigation schedule from (2 times weekly at summer/ off at winter) to (on at summer/ off at winter) has a neglected impact on annual energy consumption. However, it increases annual energy consumption by $0.19 \%$ when ST is $15 \mathrm{~cm}$, LAI is 5 and no air gap. When air gap is $2 \mathrm{~cm}$ (or more), changing irrigation increase annual energy consumption by $0.45 \%$ because of the weakness of insulation effect due to wet soil.
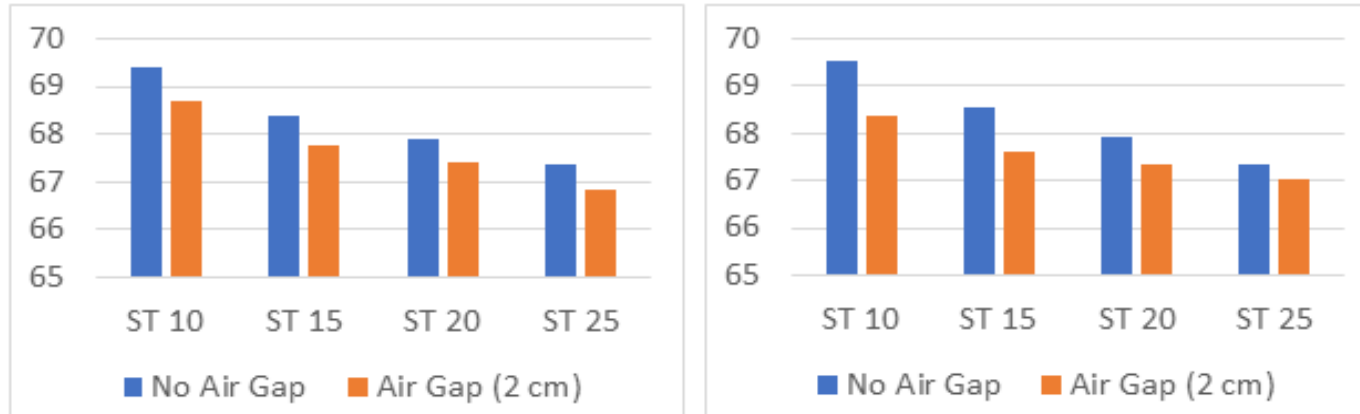

Fig. 6. Comparing the Effect of Irrigation (Left: Schedule, Right: On) on Green Roof Performance for Deferent Soil Thickness (ST) and Air Gap

\section{5. $\mathrm{CO}_{2}$ Reduction}

There is a strong correlation between annual energy consumption and $\mathrm{CO}_{2}$ production. When increase annual energy consumption, the $\mathrm{CO}_{2}$ production increase automatically. Installing green roof can help reduce annual $\mathrm{CO}_{2}$ production up to $3.68 \%$.

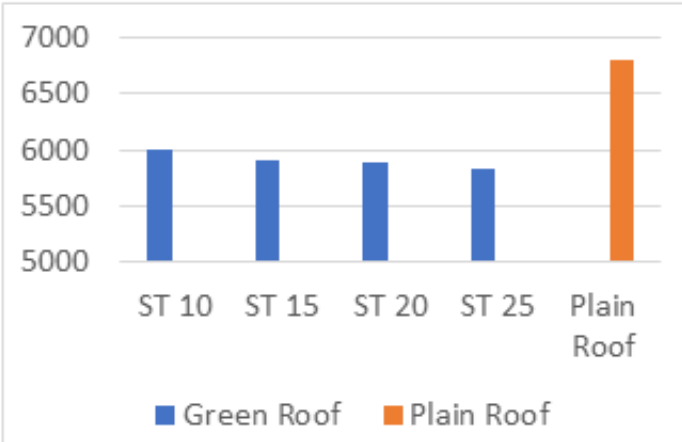

Fig. 7. Comparing Annual $\mathrm{CO}_{2}$ Production (kg) of Plain Roof With Deferent Green Roof Soil Thickness (ST) 
JES, Assiut University, Faculty of Engineering, Vol. 46, No. 6, November 2018, pp.738-753

\section{Conclusion}

The presented study has investigated the impact of soil thickness, air gap and irrigation on green roof energy performance for residential buildings under semi-arid Mediterranean climatic conditions of Amman. Annual energy consumption decreases by increase soil thickness and leaving a layer of air gap ( $2 \mathrm{~cm}$ or more). The simulations investigated the effect of green roofs compared to plain roof to determine the energy saving and $\mathrm{CO}_{2}$ reduction of green roof. Results showed that the effect of the green roof was considerable compared to the traditional plain and a consistently positive impact on $\mathrm{CO}_{2}$ reduction up to $3.68 \%$. Installing green roof on existing buildings would save annual energy consumption up to $14.25 \%$ depending on the studied factors in this work. Increasing soil thickness and air gap will increase energy saving due its insulation effect. Irrigation has a neglected impact on energy saving.

\section{Recommendations}

To save annual energy, it should be focused on heating load as residential buildings in Amman use almost the half of electricity for heating. Also, as $\mathrm{CO}_{2}$ production affected by heating demand more than cooing demand is it's the dominant.

To maximize green roof performance, it's recommended to increase soil thickness, leave $2(\mathrm{~cm})$ or more of layer of air between roof and soil. Choosing plants that need to be irrigate twice or less weekly because wet soil limit its insulation effect.

\section{Limitations of study and future research}

The validation of the simulation model was limited to one plant type. Future research to investigate other types of productive vegetation and their direct impact on energy saving.

\section{Abbreviations}

Under here a list of abbreviations that used in this work.

\begin{tabular}{|l|l|}
\hline $\mathrm{CO}_{2}$ & Carbon Dioxide \\
\hline GHG & Green House Gas \\
\hline HVAC & Heating, Ventilation, and Air Conditioning \\
\hline DHW & Domestic Hot Water \\
\hline ASHRAE & American Society of Heating, Refrigerating, and Air-Conditioning Engineers \\
\hline JNBC & National Jordanian Building Council \\
\hline SHGC & Solar Heat Gain Coefficient \\
\hline VLT & Visible Light Transmittance \\
\hline ST & Soil Thickness \\
\hline LAI & Leaf Area Index \\
\hline JOD & Jordanian Dinar \\
\hline USD & U.S. dollars \\
\hline LEED & Leadership in Energy and Environmental Design \\
\hline
\end{tabular}

\section{REFERENCES}

[1] Jamal Alnsour, "The Relationship Between Dwelling Area and Energy Consumption in Jordan, IJER Serials Publications”, Vol. 12, No. 1, pp. 61-76, 2015.

[2] General Population and Housing Census of Jordan 2015, UNICEF official webpage https://www.unicef.org/jordan

[3] Al-Bakri, J.T.; Salahat, M.; Suleiman, A.; Suifan, M.; Hamdan, M.R.; Khresat, S.; Kandakji, T., "Impact of Climate and Land Use Changes on Water and Food Security in 
Jordan: Implications for Transcending (The Tragedy of the Commons)", Sustainability, Vol. 5, pp. 724-748, 2013.

[4] J.O. Jaber, FawwazElkarmi, EmilAlasis, AnagnostopoulosKostas, "Employment of renewable energy in Jordan: Current status, SWOT and problem analysis", Renewable and Sustainable Energy Reviews, Vol. 49, pp. 490-499, 2015.

[5] Energy Profile of Jordan, The Regional Centre for Renewable Energy and Energy Efficiency (RECREEE) the official webpage http://www.rcreee.org/content/jordan

[6] Samer Zawaydeh, "Implementing Codes and Regulations as a Driver to Low Energy Buildings - Case Study, Sustainable Vital Technologies in Engineering \& Informatics", First BUE Annual Conference \& Exhibition BUEACE1 2016 7-9 November, Cairo, Egypt, pp. 1-18, 2016.

[7] Energy Annual Report, Ministry of Energy and Mineral Resources, 2016, P/25,31. Available online at:http://www.memr.gov.jo/echobusv3.0/SystemAssets/333853a2-7d894021-80f3-449f89707679.pdf

[8] Ahmed Al-Salaymeh, Heba AlZaben, Nadeen Habash, "Investigation of the Current Energy Sector in Jordan: Energy Strategy", Resources and Regulatory Framework, Jordan, International Journal of Thermal \& Environmental Engineering, Vol. 12, No. 2, pp. 89-93, 2016.

[9] Survey of Energy Consumption in the Household Sector 2013, Ministry of Energy and Mineral Resources, The Hashemite Kingdome of Jordan, Ministry's Annual Reports, 2013, P/3. Available online at the official webpage: http://www.memr.gov.jo/EchoBusv3.0/SystemAssets/PDFs/AR/Studies/householdsurveyp.pdf

[10] Carbon Dioxide Information Analysis Center, Environmental Sciences Division, Oak Ridge National Laboratory, Tennessee, United States. Available online at:

a. https://data.worldbank.org/indicator/EN.ATM.CO2E.KT?locations=JO

[11] Cristina M. Silva, M. Glória Gomes, Marcelo Silva, "Green roofs energy performance in Mediterranean climate", Energy and Buildings, Vol. 116, pp. 318-325, 2016.

[12] Gabriel Pérez, Julià Coma, Cristian Solé, Albert Castell, Luisa F. Cabeza, "Green roofs as passive system for energy savings when using rubber crumbs as drainage layer", Energy Procedia, Vol. 30, pp. 452 - 460, 2012.

[13] Jawdat Goussous, Hadi Siam, Hussain Alzoubi, "Prospects of green roof technology for energy and thermal benefits in Buildings (Case of Jordan)", Sustainable Cities and Society, Vol. 14, pp. 425-440, 2014.

[14]F. Olivieri, C. Di Perna, M. D’Orazio, L. Olivieri, J. Neila , "Experimental Measurements and Numerical Model for the Summer Performance Assessment of Extensive Green Roofs in a Mediterranean Coastal Climate”, Energy and Buildings, Vol. 63, pp. 1-14, 2013.

[15] Kristin L. Getter, D. Bradley Rowe, "The Role of Extensive Green Roofs in Sustainable Development”, HORTSCIENCE, Vol. 41, No. 5, pp. 1276-1285, 2006.

[16] Basil Kamel, Sherine Wahba, Khaled Nassar and Ahmed Abdelsalam, "Effectiveness of Green-Roof on Reducing Energy Consumption through Simulation program for a Residential Building: Cairo, Egypt", Construction Research Congress, ASCE 2012, pp. 1740-1749, 2012.

[17] Issa Jaffal, Salah-Eddine Ouldboukhitine, Rafik Belarbi, "A comprehensive study of the impact of green roofs on building energy performance", Renewable Energy, Vol. 43, 157$164,2012$.

[18] IMAP, Growing Green Guide: Green Roofs, Walls \& Facades Policy Options Background Paper, Melbourne: Inner Melbourne Action Plan, 2013, P/60.

[19] Mahnaz Mahmoudi Zarandi1, Neda Pakari, Faranak Zaimi, The positive effects of green roofs on environment, Jordan International Energy Conference 2011, Amman, Jordan, 2011, Pages: 1-6. 
[20]Baker, A.J.M. and Brooks, R.R, Terrestrial higher plants which hyperaccumulate metallic elements - a review of their distribution, ecology and phytochemistry, Bio recovery, Volume 1, 1989, Pages: 81-126.

[21] A. Al-Ghandoor, J.O. Jaber, I. Al-Hinti, I.M. Mansour, Residential past and future energy consumption: Potential savings and environmental impact Renewable and Sustainable Energy Reviews, Volume 13, 2009, Pages 1262-1274.

[22] JNBC, The Energy Saving Building Code, National Jordanian Building Council, Amman, Jordan, 1st Addition, 2010.

[23]JNBC, Thermal Insulation Code, National Jordanian Building Council, $2^{\text {nd }}$ Edition, Ministry of Public Works and Housing, Amman, Jordan, 2009.

[24] "A guide to GREEN roofs, walls and facades (in Melbourne and Victoria, Australia)", State of Victoria through the Department of Environment and Primary Industries, National Library of Australia Cataloguing-in-Publication data, 2014.

[25] Kristin L. Getter, D. Bradley Rowe, The Role of Extensive Green Roofs in Sustainable Development, HORTSCIENCE, Volume 41, Issue 5, 2006, Pages: 1276-1285.

[26] Liaw, Chao-Hsien, Huang, En-Hao, Tzai, Hsin-Yuan, "Green Roofs and Green Building Rating Systems", International Journal of Engineering Research and Applications, Vol. 5, No. 1 (Part 2), pp.71-77, 2015.

[27] 4 Strategies for Green Roof Maintenance. Available online at:

[28] https://www.buildings.com/article-details/articleid/15082/title/4-strategies-for-green-roofmaintenance

[29] Jordan Meteorological Department. Available online at: http://jometeo.gov.jo/ 


\section{تأثثير تصميم الاسقف الخضر اءع على توفير الطاقة في المباني السكنية

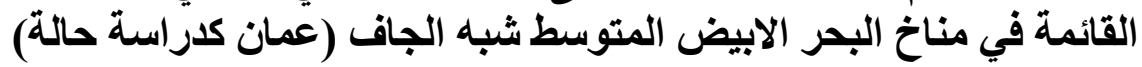

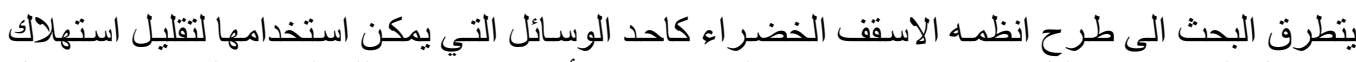

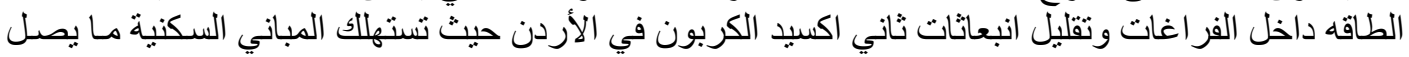

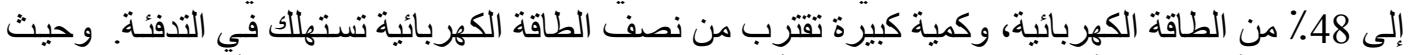

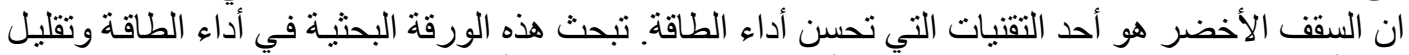

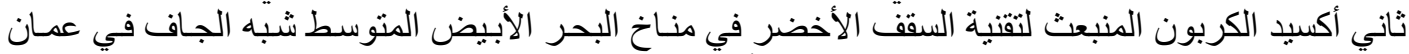

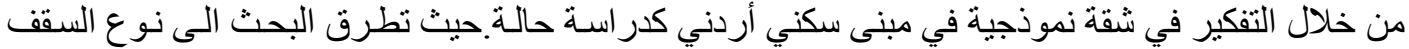

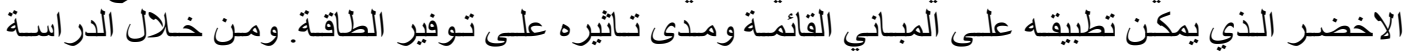

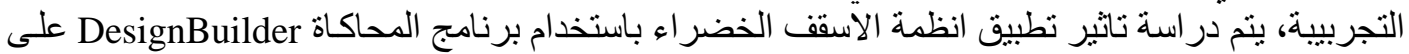

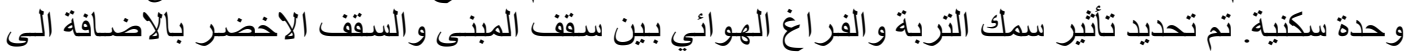

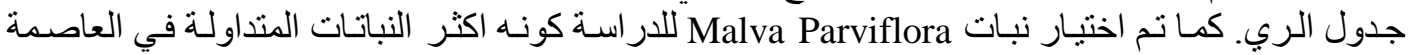

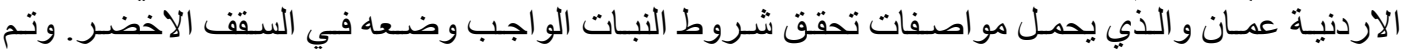

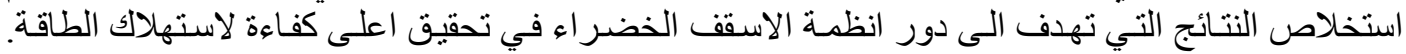

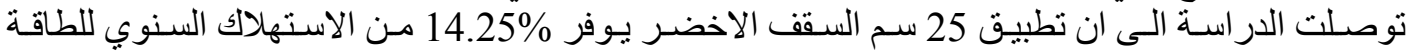
الكهربائية، و 21.24\% من الطاقة المستخدمة في التدفئة و 36.31\% من الطاقة المستخدمة في التكييف. 